\title{
Incretin Receptors for Glucagon-Like Peptide 1 and Glucose-Dependent Insulinotropic Polypeptide Are Essential for the Sustained Metabolic Actions of Vildagliptin in Mice
}

\author{
Grace Flock, Laurie L. Baggio, Christine Longuet, and Daniel J. Drucker
}

\begin{abstract}
OBJECTIVE-Dipeptidyl peptidase-4 (DPP4) inhibitors lower blood glucose in diabetic subjects; however, the mechanism of action through which these agents improve glucose homeostasis remains incompletely understood. Although glucagon-like peptide (GLP)-1 and glucose-dependent insulinotropic polypeptide (GIP) represent important targets for DPP4 activity, whether additional substrates are important for the glucose-lowering actions of DPP4 inhibitors remains uncertain.
\end{abstract}

RESEARCH DESIGN AND METHODS-We examined the efficacy of continuous vildagliptin administration in wild-type (WT) and dual incretin receptor knockout (DIRKO) mice after 8 weeks of a high-fat diet.

RESULTS-Vildagliptin had no significant effect on food intake, energy expenditure, body composition, body weight gain, or insulin sensitivity in WT or DIRKO mice. However, glycemic excursion after oral glucose challenge was significantly reduced in WT but not in DIRKO mice after vildagliptin treatment. Moreover, vildagliptin increased levels of glucose-stimulated plasma insulin and reduced levels of cholesterol and triglycerides in WT but not in DIRKO mice. Vildagliptin treatment reduced the hepatic expression of genes important for cholesterol synthesis and fatty acid oxidation, including phospho-mevalonate kinase (Mvk), acyl-coenzyme dehydrogenase medium chain (Acadm), mevalonate (diphospho)decarboxylase (Mvd), and Acyl-CoA synthetase (Acsl1), in WT but not in DIRKO mice. However, vildagliptin also reduced levels of hepatic mRNA transcripts for farnesyl di-phosphate transferase (Fdft1), acetyl coenzyme A acyltransferase 1 (Acaa1), and carnitine palmitoyl transferase 1 (Cpt 1) in DIRKO mice. No direct effect of GLP-1 receptor agonists was detected on cholesterol or triglyceride synthesis and secretion in WT hepatocytes.

From the Samuel Lunenfeld Research Institute, Department of Medicine, Mount Sinai Hospital, and the Banting and Best Diabetes Center, University of Toronto, Toronto, Canada.

Address correspondence and reprint requests to Dr. Daniel J. Drucker, Mount Sinai Hospital, SLRI Room 975C, 600 University Ave., Toronto, Ontario, M5G 1X5, Canada. E-mail: d.drucker@utoronto.ca.

Received for publication 22 May 2007 and accepted in revised form 20 August 2007.

Published ahead of print at http://diabetes.diabetesjournals.org on $23 \mathrm{Au}-$ gust 2007. DOI: $10.2337 / \mathrm{db} 07-0697$.

D.D. has served as an advisor to or consultant for Amgen, Amylin Pharmaceuticals, Arisaph Pharmaceuticals, Chugai, Conjuchem, Eli Lilly, Emlsphere Technologies, Glaxo Smith Kline, Glenmark Pharmaceuticals, Isis Pharmaceuticals, Johnson \& Johnson, Merck Research Laboratories, Merck Fr., Phenomix, Takeda, and Transition Pharmaceuticals. Laboratory research for D.D. was supported in part by Merck, Novartis, Eli Lilly, and Novo Nordisk.

Additional information for this article can be found in an online appendix at http://doi.org/10.2337/db07-0697.

BrdU, 5-bromo-2'-deoxyuridine; DPP4, dipeptidyl peptidase-4; GIP, glucosedependent insulinotropic polypeptide; GLP, glucagon-like peptide; GLP-1R, GLP-1 receptor.

(C) 2007 by the American Diabetes Association.

The costs of publication of this article were defrayed in part by the payment of page charges. This article must therefore be hereby marked "advertisement" in accordance with 18 U.S.C. Section 1734 solely to indicate this fact.
CONCLUSIONS-These findings illustrate that although GLP-1 and GIP receptors represent the dominant molecular mechanisms for transducing the glucoregulatory actions of DPP4 inhibitors, prolonged DPP4 inhibition modulates the expression of genes important for lipid metabolism independent of incretin receptor action in vivo. Diabetes 56:3006-3013, 2007

$\mathbf{I}$

ncretins are peptide hormones secreted after meal ingestion that potentiate glucose-stimulated insulin secretion. The two predominant incretins are glucose-dependent insulinotropic polypeptide (GIP) and glucagon-like peptide (GLP)-1. GIP and GLP-1 act via specific receptors on $\beta$-cells to increase insulin biosynthesis and secretion, thereby maintaining the ability of the endocrine pancreas to regulate the disposal and storage of energy after nutrient absorption (1). Both GIP and GLP-1 also exert actions on other cell types that affect energy homeostasis. GIP enhances energy storage in adipocytes, whereas GLP-1 regulates glucose homeostasis via inhibition of glucagon secretion and gastric emptying, and induction of satiety leading to long-term control of body weight (1).

The multiple actions of GLP-1 that promote reduction of blood glucose have fostered attempts to use the native peptide for the treatment of type 2 diabetes. Intermittent or continuous administration of GLP-1 reduced blood glucose and $\mathrm{A} 1 \mathrm{C}$ and improved $\beta$-cell function, demonstrating the feasibility of using GLP-1 therapy for the treatment of type 2 diabetes $(2,3)$. Nevertheless, as bioactive GLP-1 is rapidly eliminated from the circulation because of a combination of enzymatic degradation and renal clearance $(4,5)$, there is considerable interest in strategies that enhance GLP-1 action without the need for continuous administration of the native peptide.

One such approach involves the administration of degradation-resistant GLP-1 receptor (GLP-1R) agonists, such as exendin-4 (6). Synthetic exendin-4 (Exenatide) has been evaluated in clinical trials for the treatment of patients with type 2 diabetes not adequately controlled on one or more antidiabetic agents. Twice-daily administration of Exenatide via subcutaneous injection for 6 months significantly lowered blood glucose and A1C, in association with weight loss in the majority of treated subjects (7). Hence, there is increasing interest in developing long-acting GLP-1R agonists for the treatment of type 2 diabetes.

An alternative approach for enhancing incretin action involves the development of inhibitors of dipeptidyl peptidase-4 (DPP4), the principal enzyme responsible for inactivation of both GIP and GLP-1. Both incretin peptides 
contain an alanine residue at position 2 and are rapidly inactivated by $\mathrm{NH}_{2}$-terminal cleavage after secretion from gut endocrine cells $(8-10)$. The importance of endogenous DPP4 for glucose homeostasis is illustrated by the phenotype of mice with targeted inactivation of the DPP4 gene. DPP4 knockout mice exhibit reduced glycemic excursion after glucose loading, enhanced levels of GLP-1 and glucose-stimulated insulin secretion, and resistance to dietinduced obesity $(11,12)$. Furthermore, DPP4 inhibitors lower levels of blood glucose and improve $\beta$-cell function in human subjects with type 2 diabetes (13; rev. in 7 and 14). Accordingly, there is considerable interest in understanding the mechanism of action and therapeutic potential of DPP4 inhibitors in the treatment of diabetes.

Although GLP-1 and GIP are important targets for the acute glucoregulatory actions of DPP4 inhibitors, numerous additional peptides may also be DPP4 substrates and represent putative mediators of the antidiabetic actions of DPP4 (15). For example, inhibition of DPP4 activity augmented insulin secretion after exogenous administration of GLP-1, GIP, gastrin-releasing peptide, and pituitary adenylate cyclase activating polypeptide in mice (16). Furthermore, the proglucagon-derived peptide oxyntomodulin is also a substrate for DPP4 (17) and is capable of stimulating insulin secretion in vivo (18). Hence, the extent to which additional substrates, beyond GLP-1 and GIP, contribute to the glucoregulatory actions of DPP4 inhibitors remains uncertain (19).

To ascertain the importance of specific DPP4 substrates for the action of DPP4 inhibitors in vivo, we have used a genetic approach in mice. The actions of four chemically distinct DPP4 inhibitors on glycemic excursion and insulin secretion were examined in wild-type (WT) mice and in mice with genetic disruption of incretin receptor genes. Acute inhibition of DPP4 activity was associated with reduction of glycemic excursion after oral glucose loading in WT mice and in both Glp1r ${ }^{-/-}$and $\mathrm{Gipr}^{-1-}$ mice (20). In contrast, double incretin receptor knockout (DIRKO) mice failed to exhibit enhancement of insulin secretion or reduction of blood glucose after inhibition of DPP4 activity, implying that the GLP-1 and GIP receptors together are essential for the acute glucoregulatory actions of DPP4 inhibitors (20). Nevertheless, it remains possible that more sustained inhibition of DPP4 activity is associated with the recruitment and emergence of additional pathways, in addition to the GLP-1 and GIP receptors, that contribute to glucoregulatory actions in vivo. Accordingly, we have now examined the metabolic consequences of chronic administration of the DPP4 inhibitor vildagliptin for 8 weeks in high fat-fed WT and DIRKO mice.

\section{RESEARCH DESIGN AND METHODS}

The generation and characterization of DIRKO mice have been described previously (20,21). Male WT (C57BL/6; Charles River, Montreal, PQ, Canada) and DIRKO mice were housed one mouse per cage under a light/dark cycle of $12 \mathrm{~h}$ in the Toronto General Hospital animal facility with free access to food and water, except where noted. All WT mice used for these studies were acclimatized to the animal facility for several weeks before analysis. Fourweek-old mice were fed ad libitum a high-fat diet, with $45 \%$ kcal from fat (Research Diets, New Brunswick, NJ) for 6 weeks, after which groups of mice were randomized to receive either regular water or water continuously supplemented with $1 \mu \mathrm{mol} / \mathrm{ml}$ vildagliptin for 8 weeks. Assessment of fat and lean mass was carried out using a whole-body magnetic resonance analyzer (Echo Medical Systems, Houston, TX). All procedures were conducted according to protocols and guidelines approved by the Toronto General Hospital and Mount Sinai Hospital Animal Care Committees.
Glucose tolerance tests and measurement of plasma insulin, glucagon, and lipid levels. After an overnight fast, glucose (1.5 mg/g body wt) was administered orally through a gavage tube. A blood sample was drawn from a tail vein at $0,10,20,30,60,90$, and $120 \mathrm{~min}$ after glucose administration, and blood glucose levels were measured using a Glucometer Elite blood glucose meter (Bayer, Toronto, ON). For plasma insulin determinations, a blood sample $(100 \mu \mathrm{l})$ was removed from the tail vein during the 10 - to 20 -min time period after glucose administration. Blood samples were immediately mixed with 10 units/ml heparin, and plasma was separated by centrifugation at $4^{\circ} \mathrm{C}$ and stored at $-80^{\circ} \mathrm{C}$ until assayed. Plasma was assayed for insulin using a mouse insulin enzyme-linked immunoassay kit (Linco Research, St. Charles, MO). For analysis of the acute effects of vildagliptin on glucagon levels, mice were fasted overnight and then treated either with water or $0.9 \mathrm{mg} / \mathrm{ml}$ vildagliptin in the water to a dose of $5 \mathrm{mg} / \mathrm{kg}$ mouse by oral gavage. After 20 min, mice were challenged with oral glucose $(1.5 \mathrm{mg} / \mathrm{g}$ mouse), and $15 \mathrm{~min}$ later, mice were killed and blood was collected by cardiac bleed in $10 \%$ TED (5,000 KIU/ml Trasylol, $1.2 \mathrm{mg} / \mathrm{ml}$ EDTA, and $0.1 \mathrm{nmol} / \mathrm{l}$ Diprotin A). Plasma glucagon was measured using a Mouse Endocrine LINCOplex kit (Linco Research) following the manufacturer's protocol. A1C was measured using a DCA 2000+ Analyzer (Bayer, Toronto, ON). Levels of plasma cholesterol and triglycerides were measured using colorimetric assays (L-type TG kit and total cholesterol kit; Wako Chemicals, Richmond, VA).

Analysis of $\boldsymbol{\beta}$-cell area and $\boldsymbol{\beta}$-cell proliferation. After 8 weeks of vildagliptin treatment, mice were injected intraperitoneally with $100 \mathrm{mg} / \mathrm{kg} 5$-bromo-2'-deoxyuridine (BrdU) (Sigma-Aldrich, St. Louis, MO) $16 \mathrm{~h}$ before being killed. The pancreas was dissected from surrounding tissue, fixed overnight in $5 \%$ glacial acetic acid/25\% formaldehyde (vol/vol), and embedded in paraffin. Histological sections were immunostained for insulin using rabbit anti-insulin (1:30 dilution; Dako Diagnostics, Mississauga, ON, Canada) as primary antibody and biotinylated goat anti-rabbit (1:200 dilution; Vector Labs, Burlington, ON, Canada) as secondary antibody. The sections were then incubated with horseradish peroxidase-conjugated Ultra Streptavidin (ID Labs, London, ON, Canada) for $30 \mathrm{~min}$ and color was developed with freshly prepared $3,3^{\prime}$ diaminobenzidine tetrahydrochloride (DAB; Dako Diagnostics) solution. For assessment of $\beta$-cell replication, pancreatic sections were double-stained for insulin (as described above) and for BrdU using mouse anti-BrdU (1:1,000 dilution; Caltag Laboratories, Burlingame, CA) as primary antibody. After the incubation with the primary antibody, sections were exposed to biotinylated horse anti-mouse IgG (1:200 dilution; Vector Labs, Burlington, ON) and subsequently stained with horseradish peroxidase-conjugated Ultra-Streptavidin (ID Labs), and color was developed with freshly made 3,3-diaminobenzidine solution (NiDAB; Vector Labs) solution. The sections were examined using a Leica microscope (Leica Microsystems, Wetzlar, Germany) equipped with a video camera and connected to a computer with imaging software (Qwin; Leica Microsystems, Richmond Hill, ON). $\beta$-Cell area (area represented by insulin-immunopositive cells) was quantified using multiple histological sections from each pancreas and was expressed as a percentage of total pancreatic area as previously described (20-22).

Insulin tolerance tests. WT and DIRKO mice were fasted for $5 \mathrm{~h}$ and given 1.7 units/kg insulin (Humulin R, $100 \mathrm{U} / \mathrm{ml}$; Lilly, Toronto, ON, Canada) by intraperitoneal injection. Blood glucose levels were monitored at regular intervals for $4 \mathrm{~h}$ after insulin administration.

Pancreatic insulin content. Pancreas (15-20 mg) was minced and homogenized at $4^{\circ} \mathrm{C}$ in $5 \mathrm{ml}$ prechilled acid-alcohol mix (800 ml reagent alcohol +179 ml deionized water $+21 \mathrm{ml} 12 \mathrm{~N}$ sulfuric acid). The homogenate was divided in two aliquots (500 $\mu \mathrm{l}$ each) for assessment of insulin content and total protein. For analysis of insulin content, the pancreatic homogenate was centrifuged and insulin levels measured in the clarified supernatant using an insulin radioimmunoassay kit (Linco Research). For determination of total protein, the pancreatic homogenate was dried, resuspended in $200 \mu \mathrm{l} \mathrm{NaOH}$ $1 \mathrm{~N}$, and incubated at $55^{\circ} \mathrm{C}$. A Bradford assay was performed using $5 \mu$ l protein extract. Pancreatic insulin content was normalized to total protein content in each sample.

Assessment of food intake. Mice were fasted overnight (16-18 h), weighed, and then placed into individual cages containing preweighed rodent food, with free access to water. Food was reweighed at 2, 4, 8, and $24 \mathrm{~h}$, and food intake was expressed as grams of food ingested per gram of body weight.

Indirect calorimetry. Mice were placed into individual metabolic chambers with free access to food and water. Oxygen consumption was determined by indirect calorimetry using an Oxymax System (Columbus Instruments, Columbus, $\mathrm{OH}$ ). $\mathrm{VO}_{2}$ was measured at 15-min intervals for a total of $21 \mathrm{~h}$ and was normalized to body weight.

RNA preparation and quantitative real-time RT-PCR. Total RNA was extracted from the pancreas, intestine, and liver using Trizol (Sigma-Aldrich), and first-strand cDNA was synthesized from total RNA using the Superscript II synthesis system (Invitrogen, Carlsbad, CA) and random hexamers. Realtime quantitative PCR analysis was performed using TaqMan Gene Expression 
Assays and TaqMan Universal PCR Master Mix (Applied Biosystems, Foster City, CA) using the ABI Prism 7900 Sequence Detection System according to the protocols provided by the manufacturer (Applied Biosystems, Melbourne, Australia). The relative mRNA transcript levels were calculated according to the $2^{-\Delta \mathrm{CT}}$ method (23), with $\Delta \mathrm{CT}$ being the difference in cycle threshold values between the target mRNA and the 18S internal control.

Assessment of plasma DPP4 activity. Mice were fasted overnight and refed for $45 \mathrm{~min}$ before euthanization. Blood was collected from the heart in 10 units $/ \mathrm{ml}$ heparin. A total of $40 \mu \mathrm{l}$ plasma was incubated at $37^{\circ} \mathrm{C}$ in the presence of Gly-Pro $p$-nitroanilide (substrate), and the rate of its conversion into $p$-nitroaniline by DPP4 enzymatic action was monitored at $0,15,30,50$, and 60 min. Color development was measured at the 405-nm wavelength. A standard curve was obtained with known concentrations of $p$-nitroaniline. Concentration of $p$-nitroaniline produced by DPP4 action on the substrate was calculated from a standard curve. The kinetics of the enzymatic reaction are directly proportional to the slope of the curve calculated by linear regression. DPP4 activity is expressed as $\mu \mathrm{mol} / \mathrm{l}$ units of activity per minute of incubation with the substrate.

Isolation of mouse primary hepatocytes. Mice were anesthetized using isoflurane, and their abdominal cavity was exposed. The superior vena cava was clamped, the portal vein transected, and the inferior vena cava perfused with $50 \mathrm{ml}$ filter-sterilized liver perfusion media, $\mathrm{pH} 7.4$ (Invitrogen-Gibco, Burlington, ON), immediately followed by $25 \mathrm{ml}$ liver digest media, $\mathrm{pH} 7.4$ (Invitrogen-Gibco). Both the perfusion and the digest media were maintained at $37^{\circ} \mathrm{C}$ and bubbled with oxygen. The liver was removed, and hepatocytes were harvested in ice-cold hepatocyte wash media (Invitrogen-Gibco), sedimented by centrifugation at $50 \mathrm{~g}$ for $5 \mathrm{~min}$ at $4^{\circ} \mathrm{C}$ and then washed with hepatocyte wash media. Viable hepatocytes were obtained by Percoll density gradient centrifugation and resuspended in $10 \mathrm{ml}$ attachment media (Williams E media supplemented with $2 \mathrm{mmol} / \mathrm{l}$ glutMAX, $5 \%$ fetal bovine serum, 100 $\mathrm{U} / \mathrm{ml}$ penicillin, $100 \mu \mathrm{g} / \mathrm{ml}$ streptomycin [all from Invitrogen-Gibco], and 350 $\mathrm{nmol} / \mathrm{l}$ insulin). Hepatocytes were seeded into six-well plates and allowed to attach for 2-4 $\mathrm{h}$ before lipid synthesis and secretion studies or were grown overnight before cAMP production studies.

cAMP production in mouse primary hepatocytes. Mouse primary hepatocytes were maintained in Williams $\mathrm{E}$ medium supplemented with $0.1 \%$ fat-free BSA. All peptides were dissolved in PBS, and cells were treated with peptides in Williams E medium containing $100 \mu \mathrm{mol} / \mathrm{l}$ isomethyl butyl xanthine. Cells were incubated with $1 \mu \mathrm{mol} / \mathrm{l}$ exendin (9-39) or medium alone for $20 \mathrm{~min}$ at $37^{\circ} \mathrm{C}$, followed by an additional 3 -h incubation in the presence of $100 \mathrm{nmol} / \mathrm{l}$ exendin-4, GLP-1, or glucagon. Cells incubated with $100 \mu \mathrm{mol} / /$ forskolin were used as a positive control. All reactions were carried out in triplicate and terminated by the addition of ice-cold absolute ethanol. Cell extracts and media were collected and stored at $-80^{\circ} \mathrm{C}$ until assayed. cAMP concentration was measured in desiccated aliquots of ethanol extracts using a cAMP radioimmunoassay kit (Biomedical Technologies, Stoughton, MA).

Lipid synthesis and secretion in mouse primary hepatocytes. Mouse primary hepatocytes were seeded at a density of 1 million cells/well into six-well plates and labeled with $\left[\mathrm{H}^{3}\right]$ acetate (Perkin Elmer, Waltham, MA; for fatty acid and cholesterol synthesis and secretion) and $\left[\mathrm{H}^{3}\right]$ oleate (Perkin Elmer; for cholesterol ester and triglyceride synthesis and secretion) in Williams E medium supplemented with $5 \%$ fetal bovine serum for $16 \mathrm{~h}$ in the presence of PBS or $40 \mathrm{nmol} / \mathrm{l}$ exendin-4 dissolved in PBS. Media was collected and the cells washed with PBS. Lipids were extracted twice from media and cells using hexane:isopropanol 3:2 (vol/vol). The organic solvent was evaporated under vacuum, and lipids were resuspended in ice-cold hexane and resolved by thin-layer chromatography. Areas of the thin-layer chromatography plate corresponding to lipid standards for cholesterol, fatty acids, triglycerides, and cholesterol esters were cut out and mixed overnight with a scintillation cocktail. The radioactivity in each sample was measured by scintillation counting. After lipid extraction, cells were lysed in $50 \mathrm{mmol} / \mathrm{l}$ $\mathrm{NaOH}$ and protein content determined using the Bio-Rad Protein Assay (Bio-Rad, Hercules, CA). All reactions were carried out in quadruplicate.

Statistical analysis. All results are expressed as means \pm SE. Statistical significance was assessed by ANOVA and, where appropriate, a Student's $t$ test using GraphPad Prism 3 (GraphPad Software, San Diego, CA). A $P$ value of $<0.05$ was considered to be statistically significant.

\section{RESULTS}

To ascertain whether continuous administration of vildagliptin (supplied at $1 \mu \mathrm{mol} / \mathrm{ml}$ in the drinking water) was associated with suppression of plasma DPP4 activity, we measured DPP4 activity after 8 weeks of vildagliptin administration. Plasma DPP4 activity was significantly reduced in WT mice treated with vildagliptin (Fig. 1, $P<$

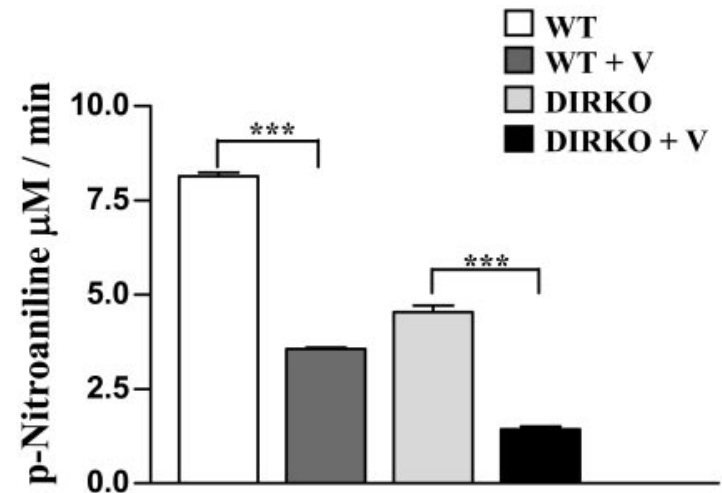

FIG. 1. Vildagliptin (V) reduces DPP4 activity in C57BL/6 WT and DIRKO mice after 8 weeks of therapy. Plasma samples were collected at the end of the 8-week experiment in 10 units $/ \mathrm{ml}$ heparin ( $n=9$ mice per group). DPP4 activity was measured by a colorimetric assay using Gly-Pro $p$-nitroanilide as substrate. Color development due to the conversion of the substrate into $p$-nitroaniline by DPP4 enzymatic action was measured at times $0,15,30,45$, and 60 min (405-nm wavelength). $* * * P<0.001$.

0.001). Furthermore, baseline plasma DPP4 activity was even lower in DIRKO mice relative to WT mice and even more markedly suppressed in DIRKO mice treated with vildagliptin (Fig. 1). These findings illustrate that continuous administration of vildagliptin suppresses plasma DPP4 activity in both WT and DIRKO mice.

Vildagliptin treatment for 7 weeks significantly reduced glycemic excursion after oral glucose loading in WT mice, in association with an increase in plasma levels of insulin (Fig. 2A-C). In contrast, vildagliptin had no effect on glycemic excursion or levels of plasma insulin in DIRKO mice (Fig. $2 A-C$ ). Although plasma glucagon levels were not significantly different after chronic vildagliptin therapy in WT or DIRKO mice (Fig. $2 D$ ), acute administration of vildagliptin was associated with marked suppression of plasma glucagon in WT but not DIRKO mice (data not shown).

To determine whether the improvement in glucose
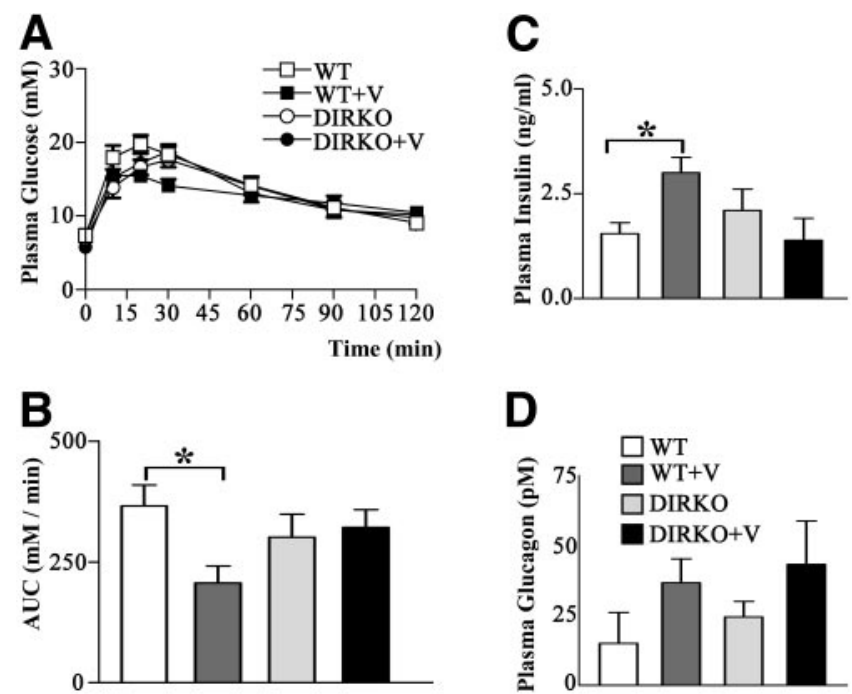

FIG. 2. Vildagliptin (V) significantly reduces glycemic excursion and increases levels of glucose-stimulated plasma insulin after an oral glucose tolerance test in C57BL/6 WT mice but not in DIRKO mice. $A$ : OGTT in WT and DIRKO mice (OGTT) $(n=8-9$ per group). $B$ : Area under the curve (AUC) for total glycemic excursion during the OGTT. $* P<0.05$. $C$ and $D$ : Plasma insulin $(C)$ and plasma glucagon $(D)$ levels at the 10- to 20 -min time point after glucose administration. $* P<0.05$. 

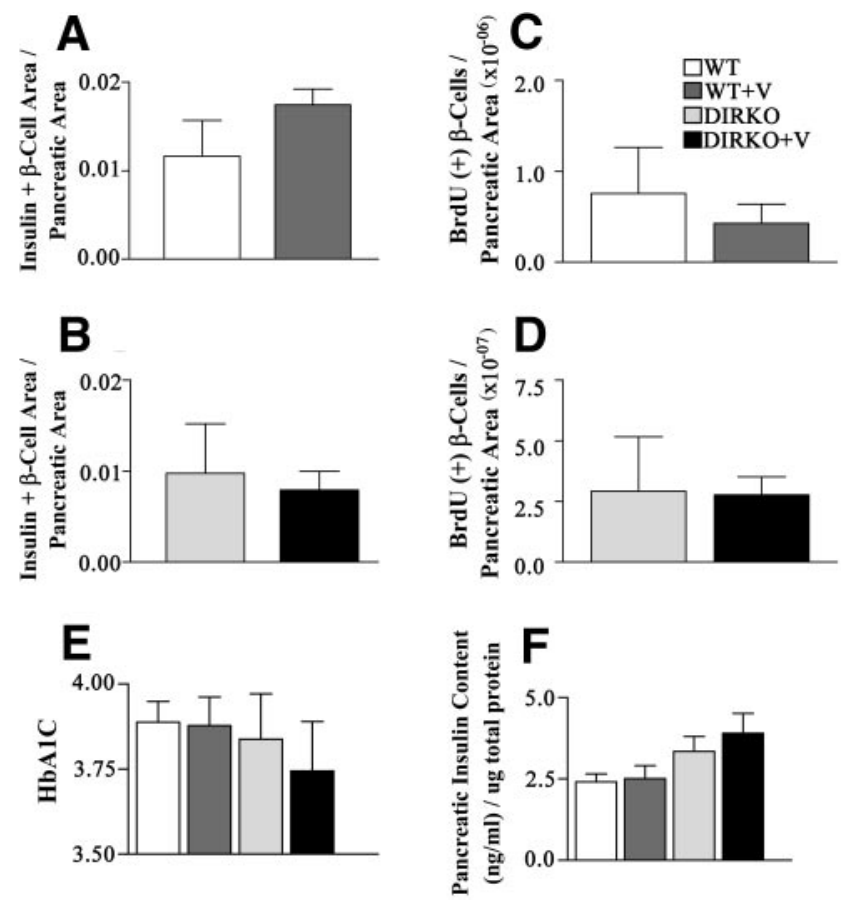

FIG. 3. Vildagliptin (V) therapy has no effect on $\beta$-cell area in C57BL/6 WT or in DIRKO mice after 8 weeks of treatment. $A$ and $B$ : Total $\beta$-cell area per total pancreatic area $(n=13-14$ mice per group). Histological sections from the pancreas were stained for insulin as described in RESEARCH DESIGN AND METHODS, and insulin-positive $\beta$-cell area was measured and normalized for total section area. $C$ and $D$ : Number of $\mathrm{BrdU}^{+} \beta$-cells per pancreatic area $(n=8-9$ mice per group). Sections were stained for BrdU as described in RESEARCH DESIGN AND METHODS, and insulin-positive $\mathrm{BrdU}^{+}$cells were counted and normalized for pancreatic area. $E$ and $F$ : Levels of A1C $(E)$ and pancreatic insulin content $(F)$ were determined in WT and DIRKO mice as described in RESEARCH DESIGN AND METHODS.

tolerance observed in WT mice after vildagliptin therapy was due in part to incretin-mediated changes in body weight and/or insulin sensitivity, we assessed energy expenditure, food intake, body weight, and the glycemic response to insulin administration in WT and DIRKO mice. Although body weight gain was significantly greater in high fat-fed WT versus DIRKO mice as described (21), vildagliptin treatment had no effect on body weight, food intake, or energy expenditure in WT or DIRKO mice (Supplementary Fig. $1 A-D$ [available in an online-only appendix at http://doi.org/10.2337/db07-0697]). Moreover, fat mass and lean body mass were comparable in WT versus DIRKO mice at the start of the study, and we did not detect changes in these parameters after vildagliptin treatment of WT or DIRKO mice (Supplementary Fig. $1 G$ and $H$ ). Although DIRKO mice were more sensitive to exogenous insulin administration as previously described (21), vildagliptin had no effect on the rate of reduction or recovery of plasma glucose observed after insulin administration in WT or DIRKO mice (Supplementary Fig. 2).

As exogenous administration of GLP-1 or GIP has been associated with expansion of islet mass via enhancement of $\beta$-cell proliferation and survival (24), we examined islet histology in WT and DIRKO mice. No differences in $\beta$-cell area or $\beta$-cell replication were observed in WT or DIRKO mice after vildagliptin administration (Fig. $3 A-D$ ), although vildagliptin-treated WT mice exhibited a modest but nonsignificant increase in $\beta$-cell area after 8 weeks of therapy (Fig. 3A). Furthermore, no differences in $\beta$-cell replication were observed in WT or DIRKO mice after
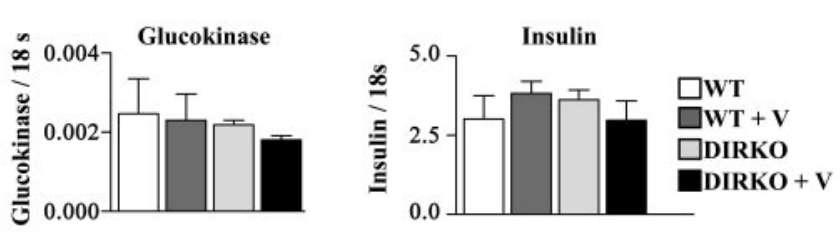

cAMP Responsive Element
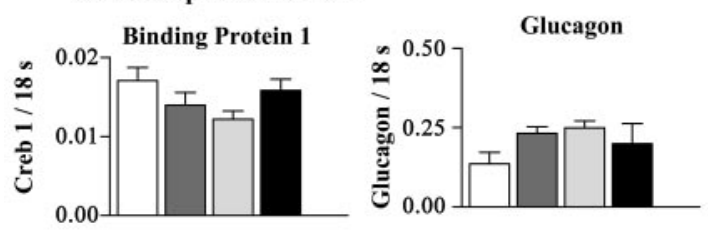

Pancreatic and Duodenal homeobox 1
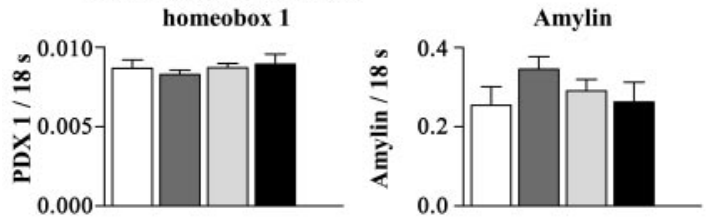

FIG. 4. Relative levels of pancreatic mRNA transcripts in vildagliptin (V)-treated WT and DIRKO mice. Levels of pancreatic mRNA transcripts for glucagon, insulin, amylin, PDX-1, cyclic AMP response element binding protein (Creb1), and glucokinase were determined by RT-PCR and normalized to levels of $18 \mathrm{~S}$ ribosomal RNA.

vildagliptin administration (Fig. $3 A-D$ ), and vildagliptin had no significant effect on levels of A1C (Fig. $3 E$ ) or pancreatic insulin content (Fig. $3 F^{\prime}$ ). We next analyzed the expression of a panel of genes known to be important for the function of differentiated islet cells, some of which have been shown to be induced after administration of GLP-1R agonists (1). Vildagliptin treatment had no significant effect on levels of mRNA transcripts for insulin, glucagon, amylin, glucokinase, cyclic AMP response element binding protein, or pancreatic and duodenal homeobox-1 in WT or DIRKO mice (Fig. 4).

Vildagliptin administration for 4 weeks improved plasma lipid profiles in subjects with type 2 diabetes (25). Accordingly, we assessed plasma lipids in WT and DIRKO mice. Vildagliptin therapy was associated with a significant reduction in levels of plasma cholesterol in WT mice (Fig. 5A). In contrast, although levels of plasma cholesterol and triglycerides were lower in DIRKO versus WT mice, no changes in plasma lipids were observed after vildagliptin treatment in DIRKO mice (Fig. $5 A$ and $B$ ).

To determine whether the reduction in plasma lipids observed in vildagliptin-treated WT mice was associated with changes in the expression of hepatic genes encoding enzymes important for lipid biosynthesis or oxidation, we compared the levels of specific mRNA transcripts in liver from vildagliptin- or vehicle-treated WT and DIRKO mice (Table 1 and Fig. $5 C$ and $D$ ). Several distinct gene expression profiles were observed in liver RNA samples from WT and DIRKO mice. A significant reduction in levels of hepatic mRNA transcripts for phosphomevalonate kinase (MVK), diphosphomevalonate decarboxylase (MVD), farnesyl diphosphate transferase 1 (Fdft1), acyl-CoA dehydrogenase (ACADM), and long-chain acyl-CoA synthetase (Acsl1) was observed after vildagliptin treatment of WT mice (Fig. $5 C$ and $D$ ). In contrast to the lack of effect of vildagliptin on glucose tolerance or plasma lipids in DIRKO mice, vildagliptin therapy was associated with reduction in levels of Fdft1, acetyl-coenzyme A acyltransferase (Acaa1), and carnitine palmitoyltransferase 1 
A

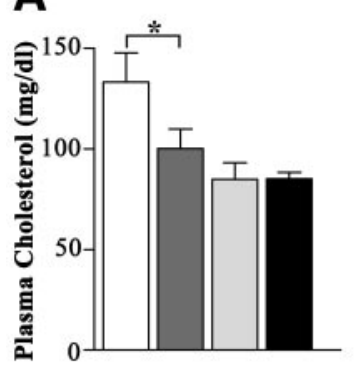

B

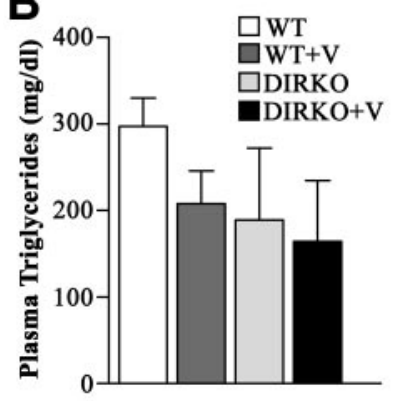

D

Farnesyl Di-Phosphate Transferase (Fdft1)
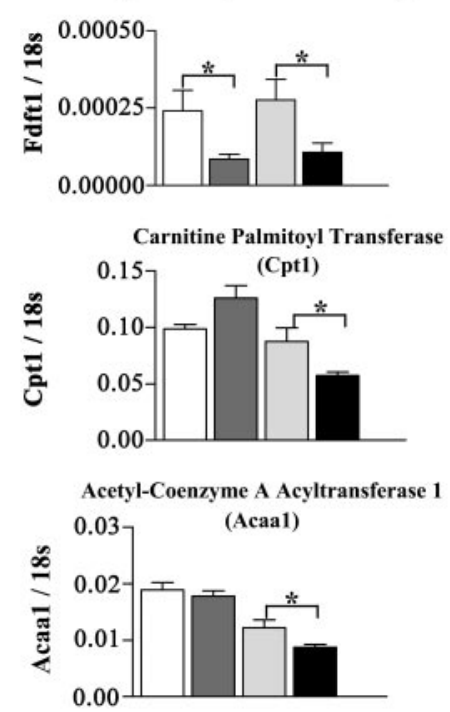

C

Di-P Mevalonate Decarboxilase (Mvd)
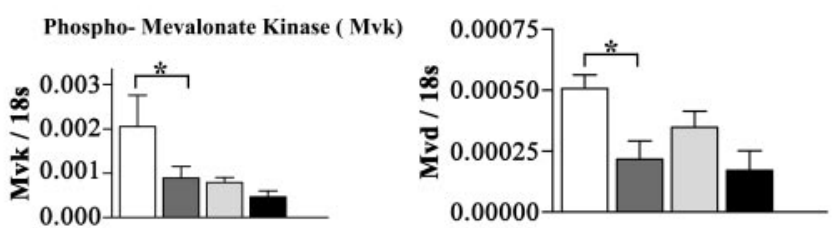

Acyl-Coenzyme A Dehydrogenase medium chain (Acadam)
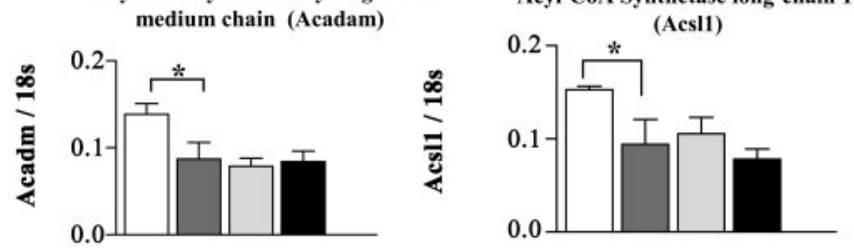

Acyl-CoA Synthetase long-chain 1

E


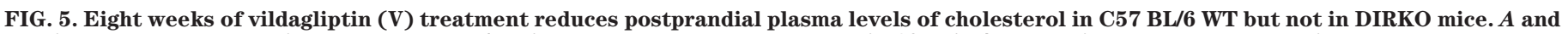

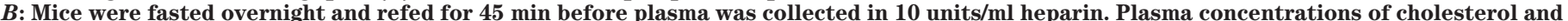

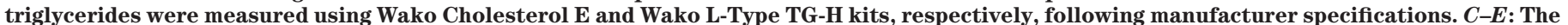

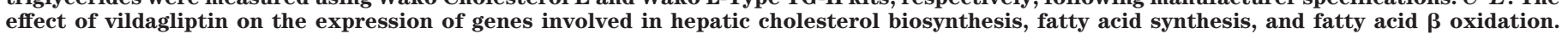

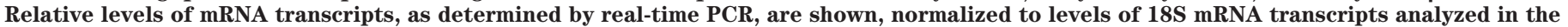
same samples and experiments. $* P<0.05, * * P<0.01, * * * P<0.001$.

(CPT1) mRNA transcripts in DIRKO mice (Fig. 5D). A third grouping of mRNA transcripts encoding for enzymes involved in the lipid biosynthesis or oxidation pathways represented genes whose expression patterns were not changed by vildagliptin treatment in either WT or DIRKO mice, including squalene epoxidase, acyl-coenzyme A carboxylase $\beta$, stearoyl CoA desaturase 1 (SCD1), fatty acid desaturase 1 and 2 (Fads1 and Fads2), and carnitine acetyltransferase (Crat) (Table 1 and Supplementary Fig. 3).

As human studies have demonstrated that vildagliptin administration to subjects with type 2 diabetes was associated with reduction in plasma levels of intestinal-derived triglyceride-rich lipoproteins (25), we examined whether vildagliptin treatment of WT or DIRKO mice was associated with changes in the expression of genes encoding key enzymes involved in intestinal lipid transport and/or biosynthesis. Vildagliptin had no effect on levels of intestinal mRNA transcripts for microsomal triglyceride transfer protein (MTTP), fatty acid transport protein 1 (FATP1), apolipoprotein B mRNA editing enzyme (Apobec)-1, or lipoprotein lipase (Lpl) (Fig. 5E).

We hypothesized that vildagliptin, by enhancing levels of bioactive GLP-1, might directly modulate hepatic lipid synthesis or secretion. As GLP-1 and exendin-4 were reported to regulate the expression of genes encoding 
TABLE 1

Vildagliptin-regulated hepatic gene expression

\begin{tabular}{lcc}
\hline & WT & DIRKO \\
\hline Mvk & + & - \\
Acadm & + & - \\
Acsl1 & + & - \\
Mvd & + & - \\
Fdft1 & + & + \\
Cpt1 & - & + \\
Acaa1 & - & + \\
Crat & - & - \\
Acads & - & - \\
Hadha & - & - \\
Apo-4 & - & - \\
Apo-C & - & - \\
Apo-m & - & - \\
Lipg & - & - \\
Acab & - & - \\
Fads1 & - & - \\
Fads 2 & - & - \\
Scd1 & - & - \\
Lss & - & - \\
Dhcr7 & - & - \\
Sqle & - & - \\
\hline
\end{tabular}

+ , Significant effect of vildagliptin on levels of mRNA transcripts; - , lack of effect of vildagliptin. Abbreviation of mRNA transcripts are as per gene nomenclature for murine genes.

enzymes involved in lipid synthesis and oxidation in rat hepatocytes through a GLP-1 receptor-dependent pathway (26), we assessed whether the GLP-1R agonist exendin- 4 was capable of directly regulating lipid synthesis or secretion in WT murine hepatocytes in vitro. In contrast to data obtained with rat hepatocytes, exendin-4 had no effect on cholesterol, cholesterol ester, free fatty acid, or triglyceride synthesis (Fig. 6, upper panels) or secretion (Fig. 6, lower panels) in murine hepatocytes. Furthermore, we did not detect GLP-1R mRNA. transcripts by PCR analysis of RNA isolated from cultured murine hepatocytes (data not shown), and we were unable to detect any stimulation of cyclic AMP formation after incubation of murine hepatocytes with GLP-1 or exendin-4. In contrast, both glucagon and forskolin significantly increased levels of hepatocyte cyclic AMP in the same experiments (Supplementary Fig. 4).

Because therapy with DPP4 inhibitors such as vildagliptin and sitagliptin has been associated with increased plasma levels of GLP-1 and GIP in both the fasting and postprandial states $(27,28)$, we assessed whether vildagliptin modulates incretin biosynthesis by examining the levels of mRNA transcripts for GIP and proglucagon in the duodenum and ileum of WT mice. No changes in the relative levels of proglucagon, GIP, or DPP4 mRNA transcripts were detected in the small bowel of mice treated with vildagliptin for 8 weeks relative to vehicle-treated control mice, indicating that chronic DPP4 inhibition is not associated with induction of incretin gene expression (Supplementary Fig. 5).

\section{DISCUSSION}

DPP4 is a ubiquitously expressed protease that exists as both a membrane-anchored protein and a soluble form widely distributed in the circulation. Both molecular species of DPP4 retain their catalytic activity and are capable of cleaving a broad spectrum of peptides with an alanine or proline at position 2 (29). The best characterized DPP4 substrates with glucoregulatory activity are the incretin peptides GIP and GLP-1. Circulating levels of intact GLP-1
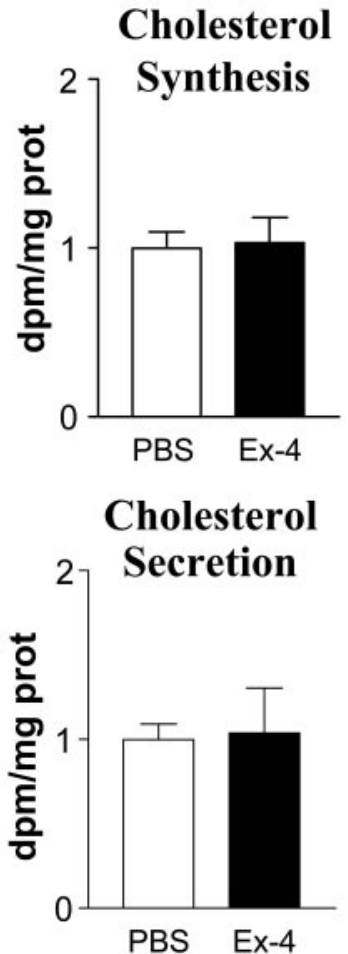
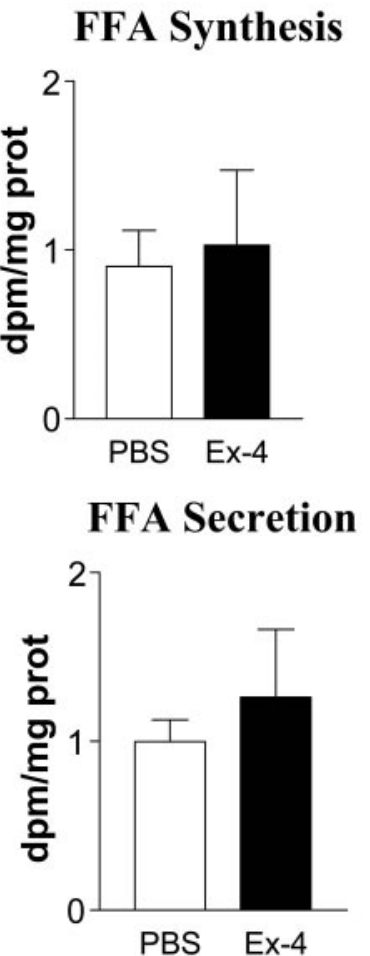
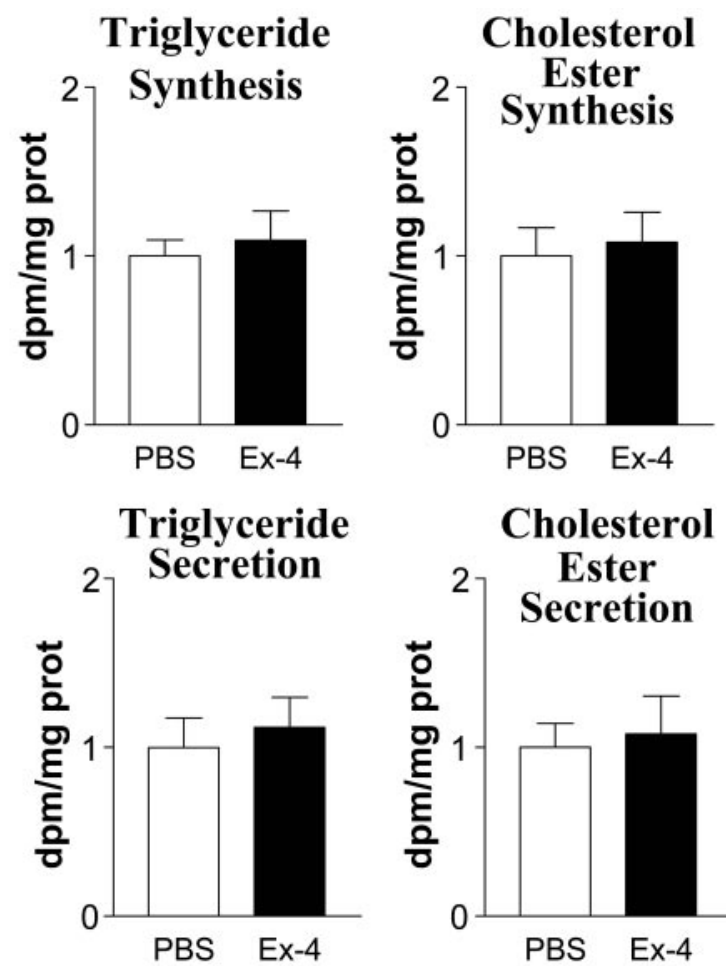

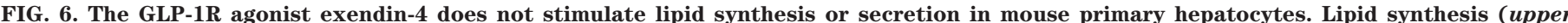

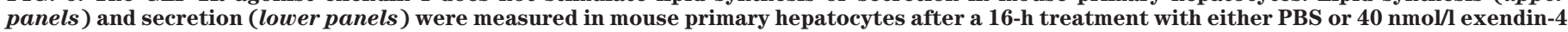

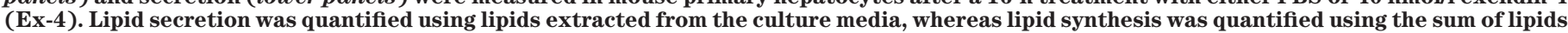
extracted from the culture media and cells. The data are means $\pm \mathrm{SE}$ of reactions carried out in quadruplicate. 
and GIP are dependent on the presence of DPP4 activity, since DPP4 ${ }^{-1-}$ mice exhibit increased circulating levels of intact incretin peptides (11) and therapy with DPP4 inhibitors is associated with increased levels of bioactive GIP and GLP-1. These findings, taken together with the demonstration that the acute glucose-lowering actions of DPP4 inhibitors are abrogated in DIRKO mice (20), strongly implicate an important role for GIP and GLP-1 as key transducers of the antidiabetic actions of DPP4 inhibitors.

Nevertheless, the observation that multiple additional DPP4 substrates regulate food intake and $\beta$-cell function, including enterostatin, pituitary adenylate cyclase-activating polypeptide, gastrin-releasing peptide, PYY, and oxyntomodulin, raises the possibility that DPP4 inhibition may lower blood glucose and/or produce other biological actions via modulation of peptide activity beyond GLP-1 and GIP $(15,29)$. Furthermore, although DPP4 inhibitors fail to lower blood glucose in acute short-term studies in normoglycemic DIRKO mice (20), it remains possible that chronic therapy with DPP4 inhibitors in high fat-fed DIRKO mice may recruit additional substrates that contribute to the reduction in glycemia observed after prolonged DPP4 inhibition in vivo. Our data demonstrating complete absence of glucose regulation in high fat-fed DIRKO mice after chronic continuous vildagliptin administration suggests that the GIP and GLP-1 receptors represent the predominant molecular targets for glucoregulation after sustained DPP4 inhibition in vivo. Continuous vildagliptin administration was not associated with reduction of blood glucose, inhibition of plasma glucagon, or stimulation of insulin secretion in DIRKO mice.

An important limitation of the current studies is the degree of glucose intolerance achieved after chronic highfat feeding in our experiments. Although plasma glucose levels ranged from 8 to $10 \mathrm{mmol} / \mathrm{l}$ in the fasting state and rose to $\sim 20 \mathrm{mmol} / \mathrm{l}$ after a glucose challenge, it remains possible that conditions using more severe hyperglycemia and more potent or prolonged DPP4 inhibition may reveal activities of additional DPP4 substrates beyond GLP-1 and GIP that might contribute to glucose reduction after chronic DPP4 inhibition.

In this regard, it is perhaps surprising that DPP4 inhibition was not associated with induction of incretin-responsive genes in the pancreas (such as pdx-1, insulin, or glucokinase), and we did not detect significant stimulation of $\beta$-cell proliferation or expansion of $\beta$-cell mass after vildagliptin therapy in our experiments. One simple explanation may be that the degree of DPP4 inhibition achieved in WT mice in our experiments may not be sufficient to achieve required levels of plasma incretins necessary for optimal effects on $\beta$-cell mass. Other studies have shown that DPP4 inhibition was associated with normalization but not expansion of $\beta$-cell mass in high fat-fed mice treated with des-fluoro-sitagliptin after streptozotocin administration (30). Similarly, chronic vildagliptin treatment of mice with $\beta$-cell expression of human islet amyloid polypeptide improved islet topography but did not result in significant expansion of $\beta$-cell mass (31). Hence, these studies imply that pharmacological levels of GLP-1 or GLP-1R agonists, not achieved with DPP4 inhibition, may be required for optimal expansion of $\beta$-cell mass in preclinical experiments.

Consistent with findings that vildagliptin lowers plasma cholesterol and triglycerides in subjects with type 2 diabetes (25), vildagliptin decreased levels of plasma choles- terol and triglycerides in WT mice. These findings were associated with significant changes in levels of hepatic enzymes important for cholesterol biosynthesis and/or lipid oxidation in both WT and DIRKO mice. Nevertheless, we did not observe any direct effect of GLP-1 on cholesterol or triglyceride synthesis or secretion in isolated murine hepatocytes. Hence, the reduction of plasma cholesterol observed after chronic DPP4 inhibition may be related in part to as yet unexplained effects of GLP-1 on intestinal lipid synthesis or secretion as postulated in human studies (25) or to indirect actions reflecting improved plasma glucose in vildagliptin-treated mice.

In contrast to the lack of vildagliptin-induced changes in parameters regulating glucose homeostasis in DIRKO mice, vildagliptin therapy selectively reduced the hepatic expression of Fdft1, Acaa1, and Cpt1 in DIRKO mice. These data illustrate that the mechanisms underlying the reduction in levels of cholesterol and triglycerides observed in conjunction with DPP4 inhibitor therapy (25) are likely complex, reflecting both the glucoregulatory actions of GIP and GLP-1 and additional as yet unidentified DPP4-sensitive substrates. Although DPP4 is known to be expressed in hepatocytes, there is currently no data linking changes in liver DPP4 activity to enzymatic regulation of lipid synthesis and secretion. An important caveat of our studies is that we examined the effects of only a single DPP4 inhibitor, vildagliptin, and hence we cannot be certain that some of the findings we observed were not specific to vildagliptin alone. Taken together, these data demonstrate that the GIP and GLP-1 receptors are essential for many but not all of the changes in metabolic parameters observed after chronic inhibition of DPP4. Our data suggest that additional studies characterizing the importance of DPP4 in the control of hepatic lipid synthesis and oxidation appear warranted.

\section{ACKNOWLEDGMENTS}

These studies were supported in part by grants from Novartis Pharmaceuticals, the Canadian Diabetes Association, and the Juvenile Diabetes Research Foundation. G.F. is supported by a Canada Graduate Studentship Award from the CIHR. D.J.D. is supported by a Canada Research Chair in Regulatory Peptides.

\section{REFERENCES}

1. Drucker DJ: The biology of incretin hormones. Cell Metab 3:153-165, 2006 2. Todd JF, Wilding JP, Edwards CM, Ghatei MA, Bloom SR: Glucagon-like peptide-1 (GLP-1): a trial of treatment in non-insulin-dependent diabetes mellitus. Eur J Clin Invest 27:533-536, 1997

3. Zander M, Madsbad S, Madsen JL, Holst JJ: Effect of 6-week course of glucagon-like peptide 1 on glycaemic control, insulin sensitivity, and beta-cell function in type 2 diabetes: a parallel-group study. Lancet 359:824-830, 2002

4. Deacon CF, Nauck MA, Toft-Nielsen M, Pridal L, Willms B, Holst JJ: Both subcutaneously and intravenously administered glucagon-like peptide 1 are rapidly degraded from the NH2-terminus in type II diabetic patients and in healthy subjects. Diabetes 44:1126-1131, 1995

5. Ruiz-Grande C, Pintado J, Alarcon C, Castilla C, Valverde I, Lopez-Novoa JM: Renal catabolism of human glucagon-like peptides 1 and 2. Can J Physiol Pharmacol 68:1568-1573, 1990

6. Eng J, Kleinman WA, Singh L, Singh G, Raufman JP: Isolation and characterization of exendin 4 , an exendin 3 analogue from Heloderma suspectum venom. J Biol Chem 267:7402-7405, 1992

7. Drucker DJ, Nauck MA: The incretin system: glucagon-like peptide-1 receptor agonists and dipeptidyl peptidase- 4 inhibitors in type 2 diabetes. Lancet 368:1696-1705, 2006

8. Mentlein R, Gallwitz B, Schmidt WE: Dipeptidyl-peptidase IV hydrolyses gastric inhibitory polypeptide, glucagon-like peptide-1(7-36)amide, peptide 
histidine methionine and is responsible for their degradation in human serum. Eur J Biochem 214:829-835, 1993

9. Kieffer TJ, McIntosh CH, Pederson RA: Degradation of glucose-dependent insulinotropic polypeptide and truncated glucagon-like peptide 1 in vitro and in vivo by dipeptidyl peptidase IV. Endocrinology 136:3585-3596, 1995

10. Hansen L, Deacon CF, Orskov C, Holst JJ: Glucagon-like peptide-1-(736)amide is transformed to glucagon-like peptide-1-(9-36)amide by dipeptidyl peptidase IV in the capillaries supplying the L cells of the porcine intestine. Endocrinology 140:5356-5363, 1999

11. Marguet D, Baggio L, Kobayashi T, Bernard AM, Pierres M, Nielsen PF, Ribel U, Watanabe T, Drucker DJ, Wagtmann N: Enhanced insulin secretion and improved glucose tolerance in mice lacking CD26. Proc Natl Acad Sci U S A 97:6874-6879, 2000

12. Conarello SL, Li Z, Ronan J, Roy RS, Zhu L, Jiang G, Liu F, Woods J, Zycband E, Moller DE, Thornberry NA, Zhang BB: Mice lacking dipeptidyl peptidase IV are protected against obesity and insulin resistance. Proc Natl Acad Sci U S A 100:6825-6830, 2003

13. Ahren B, Simonsson E, Larsson H, Landin-Olsson M, Torgeirsson H, Jansson PA, Sandqvist M, Bavenholm P, Efendic S, Eriksson JW, Dickinson S, Holmes D: Inhibition of dipeptidyl peptidase IV improves metabolic control over a 4 -week study period in type 2 diabetes. Diabetes Care 25:869-875, 2002

14. Ahren B: Dipeptidyl peptidase-4 inhibitors: clinical data and clinical implications. Diabetes Care 30:1344-1350, 2007

15. Drucker DJ: Dipeptidyl peptidase-4 inhibition and the treatment of type 2 diabetes: preclinical biology and mechanisms of action. Diabetes Care 30:1335-1343, 2007

16. Ahren B, Hughes TE: Inhibition of DPP-4 augments insulin secretion in response to exogenously administered GLP-1, GIP, PACAP and GRP in mice. Endocrinology 4:2055-2059, 2005

17. Zhu L, Tamvakopoulos C, Xie D, Dragovic J, Shen X, Fenyk-Melody JE, Schmidt K, Bagchi A, Griffin PR, Thornberry NA, Sinha Roy R: The role of dipeptidyl peptidase IV in the cleavage of glucagon family peptides: in vivo metabolism of pituitary adenylate cyclase activating polypeptide-(1-38). J Biol Chem 278:22418-22423, 2003

18. Jarrousse C, Bataille D, Jeanrenaud B: A pure enteroglucagon, oxyntomodulin (glucagon 37), stimulates insulin release in perfused rat pancreas. Endocrinology 115:102-105, 1984

19. Ahren B: What mediates the benefits associated with dipeptidyl peptidase-IV inhibition? Diabetologia 48:605-607, 2005

20. Hansotia T, Baggio LL, Delmeire D, Hinke SA, Yamada Y, Tsukiyama K, Seino Y, Holst JJ, Schuit F, Drucker DJ: Double incretin receptor knockout (DIRKO) mice reveal an essential role for the enteroinsular axis in transducing the glucoregulatory actions of DPP-IV inhibitors. Diabetes 53:1326-1335, 2004
21. Hansotia T, Maida A, Flock G, Yamada Y, Tsukiyama K, Seino Y, Drucker DJ: Extrapancreatic incretin receptors modulate glucose homeostasis, body weight, and energy expenditure. J Clin Invest 117:143-152, 2007

22. Kim JG, Baggio LL, Bridon DP, Castaigne JP, Robitaille MF, Jette L, Benquet C, Drucker DJ: Development and characterization of a glucagonlike peptide 1-albumin conjugate: the ability to activate the glucagon-like peptide 1 receptor in vivo. Diabetes 52:751-759, 2003

23. Livak KJ, Schmittgen TD: Analysis of relative gene expression data using real-time quantitative PCR and the 2(-Delta Delta C(T)) method. Methods 25:402-408, 2001

24. Drucker DJ: Glucagon-like peptides: regulators of cell proliferation, differentiation, and apoptosis. Mol Endocrinol 17:161-171, 2003

25. Matikainen N, Manttari S, Schweizer A, Ulvestad A, Mills D, Dunning BE, Foley JE, Taskinen MR: Vildagliptin therapy reduces postprandial intestinal triglyceride-rich lipoprotein particles in patients with type 2 diabetes. Diabetologia 49:2049-2057, 2006

26. Ding X, Saxena NK, Lin S, Gupta NA, Anania FA: Exendin-4, a glucagonlike protein-1 (GLP-1) receptor agonist, reverses hepatic steatosis in ob/ob mice. Hepatology 43:173-181, 2006

27. Mari A, Sallas WM, He YL, Watson C, Ligueros-Saylan M, Dunning BE, Deacon CF, Holst JJ, Foley JE: Vildagliptin, a dipeptidyl peptidase-IV inhibitor, improves model-assessed $\beta$-cell function in patients with type 2 diabetes. J Clin Endocrinol Metab 90:4888-4994, 2005

28. Herman GA, Bergman A, Stevens C, Kotey P, Yi B, Zhao P, Dietrich B, Golor G, Schrodter A, Keymeulen B, Lasseter KC, Kipnes MS, Snyder K, Hilliard D, Tanen M, Cilissen C, De Smet M, de Lepeleire I, Van Dyck K, Wang AQ, Zeng W, Davies MJ, Tanaka W, Holst JJ, Deacon CF, Gottesdiener KM, Wagner JA: Effect of single oral doses of sitagliptin, a dipeptidyl peptidase-4 inhibitor, on incretin and plasma glucose levels following an oral glucose tolerance test in patients with type 2 diabetes. $J$ Clin Endocrinol Metab 91:4612-4619, 2006

29. Mentlein R: Dipeptidyl-peptidase IV (CD26): role in the inactivation of regulatory peptides. Regul Pept 85:9-24, 1999

30. Mu J, Woods J, Zhou YP, Roy RS, Li Z, Zycband E, Feng Y, Zhu L, Li C, Howard AD, Moller DE, Thornberry NA, Zhang BB: Chronic inhibition of dipeptidyl peptidase- 4 with a sitagliptin analog preserves pancreatic $\beta$-cell mass and function in a rodent model of type 2 diabetes. Diabetes 55:1695-1704, 2006

31. Ahren B, Winzell MS, Wierup N, Sundler F, Burkey B, Hughes TE: DPP-4 inhibition improves glucose tolerance and increases insulin and GLP-1 responses to gastric glucose in association with normalized islet topography in mice with beta-cell-specific overexpression of human islet amyloid polypeptide. Regul Pept 143:97-103, 2007 

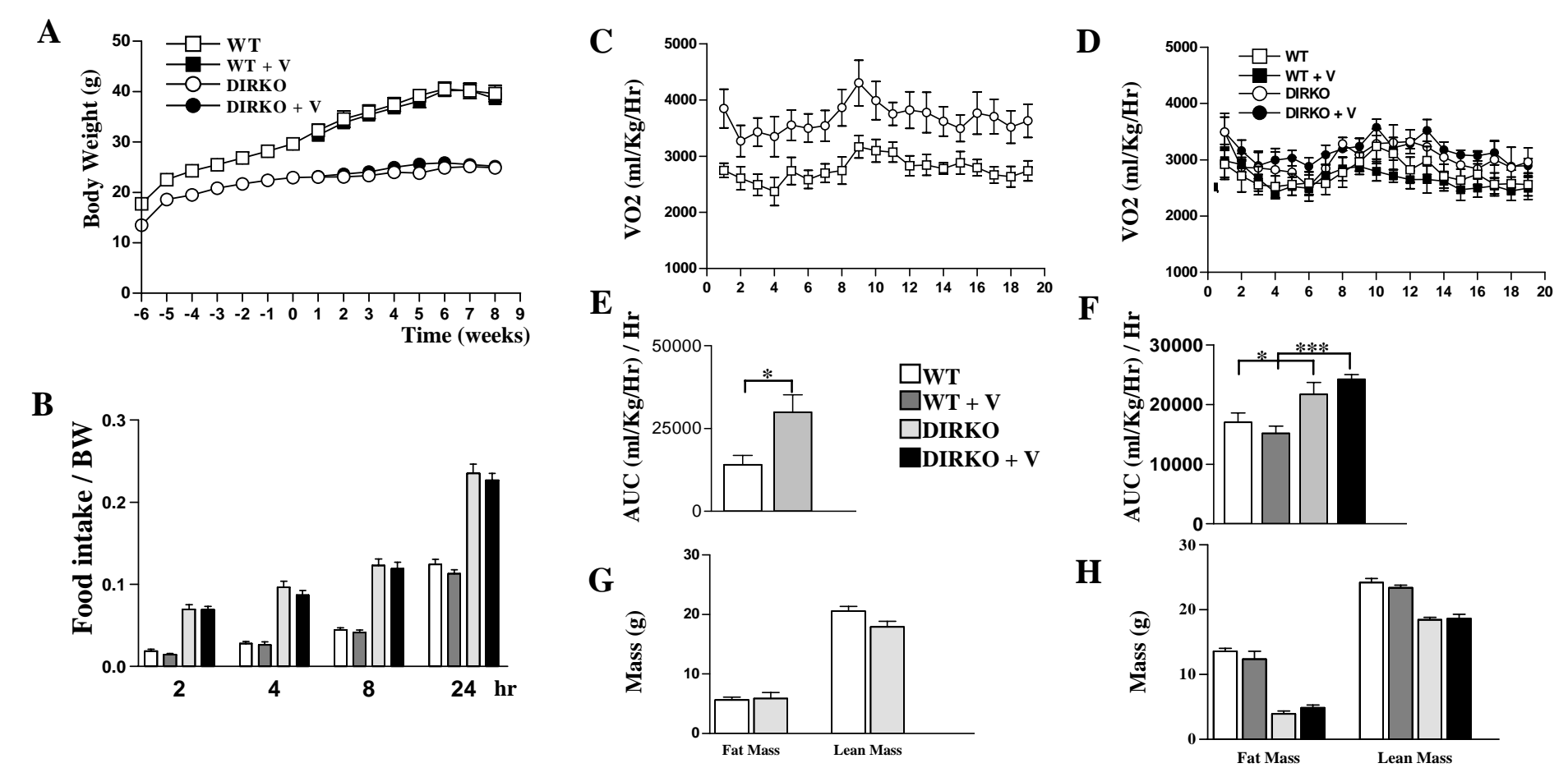

Supplementary Figure 1 


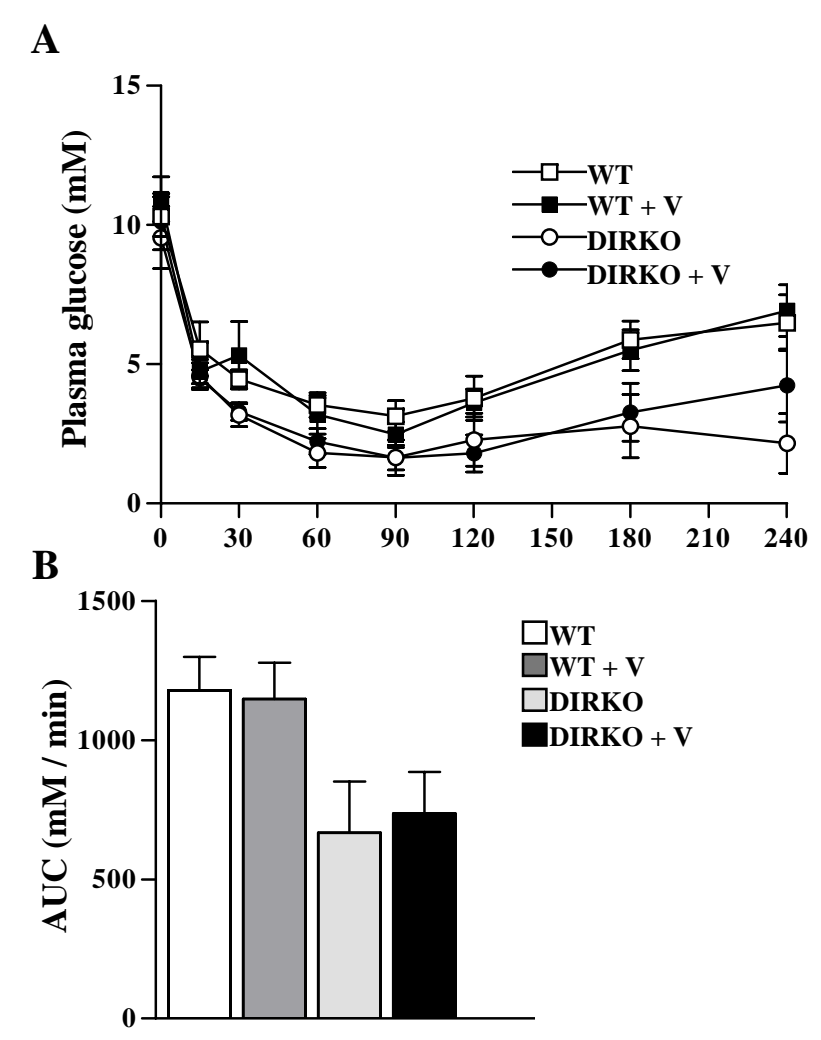

Supplementary Figure 2 


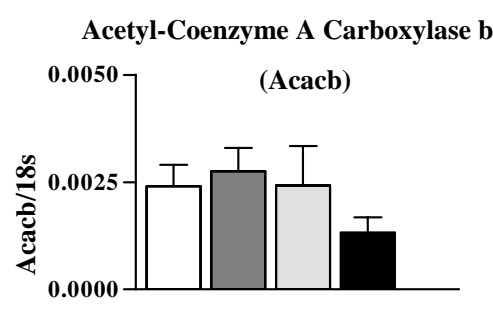

Fatty Acid Desaturase 1 (Fads1)

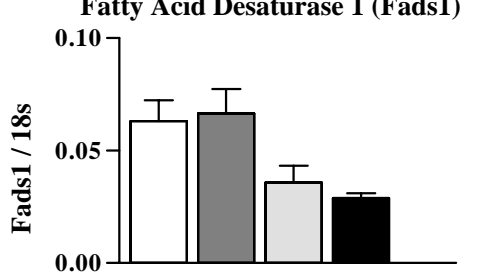

Fatty Acid Desaturase 2 (Fads 2)

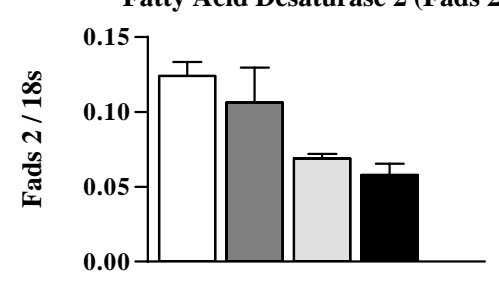

Stearoyl-CoA Desaturase (Scd1)

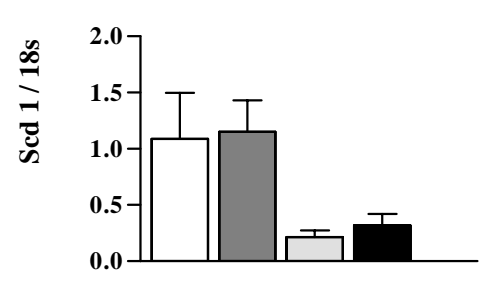

Carnitine Acetyl Transferase

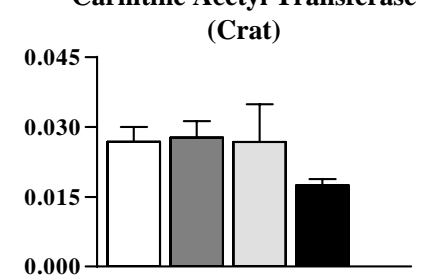

Squalene Epoxidase (Sqle)
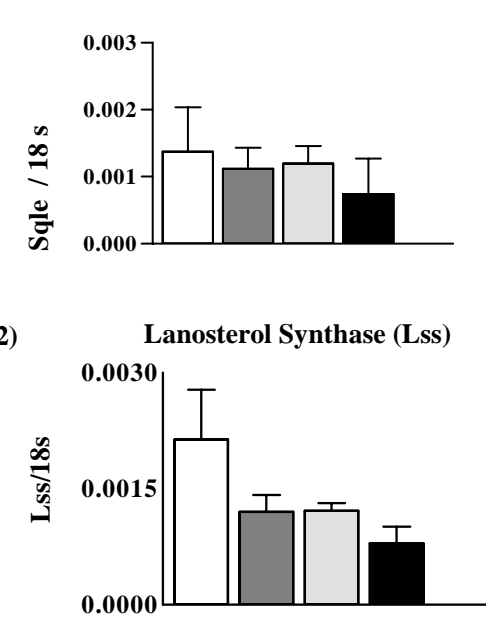
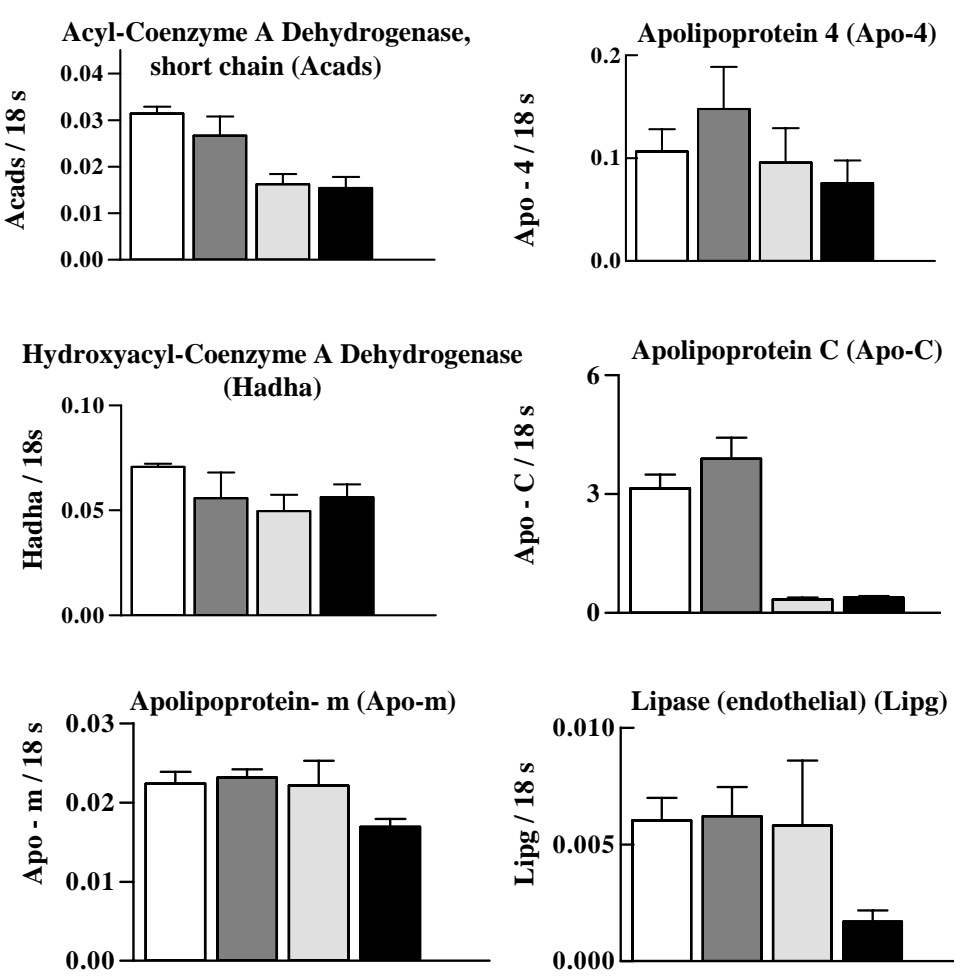

7-Dehydrocholesterol Reductase (Dhcr7)

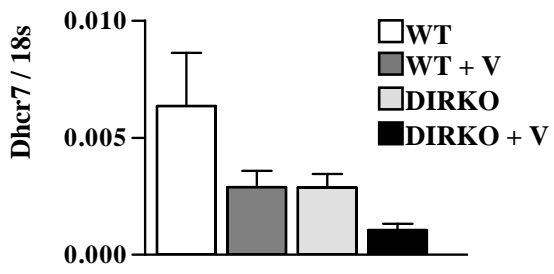

Supplementary Figure 3 


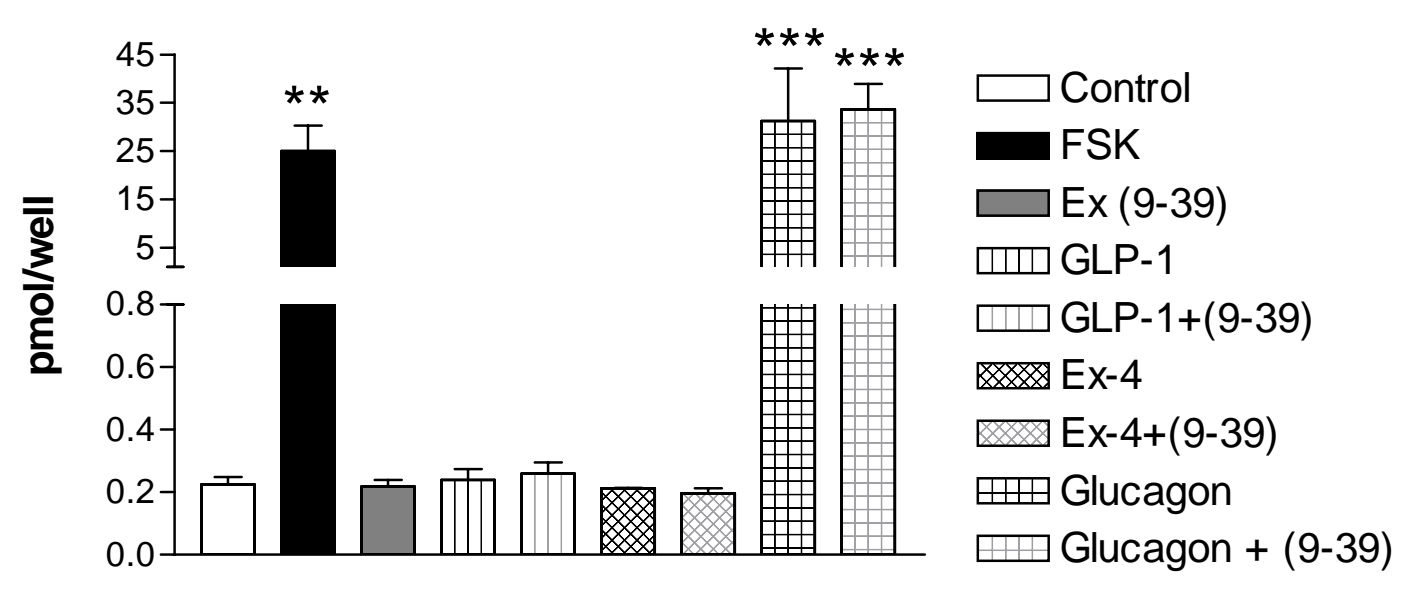

Supplementary Figure 4 
Dipeptidyl Peptidase 4 (DPP4)

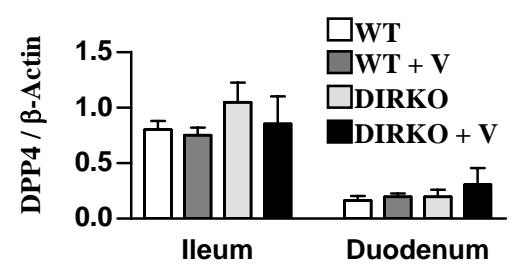

Glucose-dependent Insulinotropic Polypeptide
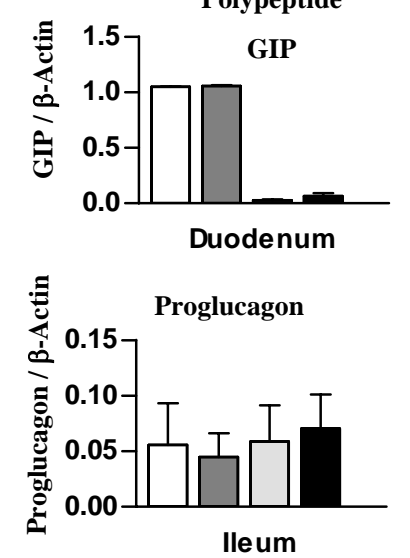

Supplementary Figure 5 


\section{Supplementary Figures \\ Supplementary Figure 1}

Vildagliptin has no effect on Body Weight, Food Intake, Oxygen Consumption and Body Composition in C57BL/6 WT and DIRKO mice after 8 weeks of therapy. (A) Body weight gain in WT and DIRKO mice, treated with vehicle or vildagliptin. (B) Food Intake. Following an overnight fast (16-18 hours), in WT and DIRKO mice, treated with or without vildagliptin. Mice were placed in individual cages, and food intake was monitored over 24 hours. Data is expressed as amount of food $(\mathrm{g})$ ingested per mouse body weight $(\mathrm{g})$. ( C, D) Oxygen consumption $\left(\mathrm{VO}_{2}\right)$ was measured during the light and dark cycles in WT and DIRKO mice before vildagliptin therapy started (C) and after 7 weeks of vildagliptin Therapy (D). Oxygen consumption was determined by indirect calorimetry using an Oxymax System (Columbus Instruments). Oxygen consumption was measured at 15-minute intervals for a total of 21 hours and was normalized to body weight. (E, F) AUC for Oxygen consumption prior to and after 7 weeks of vildagliptin therapy. $*=\mathrm{P}<0.05, * * *=\mathrm{P}<0.001(\mathbf{G}, \mathbf{H})$ Total body fat and lean mass in WT and DIRKO mice at basal $(\mathrm{G})$ and after 7 weeks of treatment $(\mathrm{H})$ with or without vildagliptin as assessed by MRI.

\section{Supplementary Figure 2}

Vildagliptin therapy does not change insulin sensitivity after 8 weeks of treatment in C57BL/6 WT and DIRKO mice. (A) Glucose levels during an insulin tolerance test in control and vildagliptin treated WT and DIRKO mice ( $\mathrm{n}=9$ per group). After 8 weeks of vildagliptin therapy, WT and DIRKO mice were fasted for 5 hours and subsequently injected with $1.7 \mathrm{U} / \mathrm{kg}$ insulin. Blood glucose levels were monitored for 4 hours following insulin administration. (B) AUC for plasma glucose following insulin administration.

\section{Supplementary Figure 3}

Vildagliptin has no effect on the relative levels of mRNA transcripts for hepatic enzymes involved in lipid biosynthesis and beta-oxidation pathways. Liver RNA was prepared and gene expression levels were determined by Real Time PCR as described in methods. Gene expression was normalized to the mRNA levels of $18 \mathrm{~s}$ as the housekeeping gene.

\section{Supplementary Figure 4}

Glucagon, but not exendin-4 or GLP-1, stimulates cAMP production in mouse primary hepatocytes. Mouse primary hepatocytes were pretreated for $20 \mathrm{~min}$ with $1 \mu \mathrm{M}$ exendin (9-39) [Ex (9-39)] or medium alone prior to a $3 \mathrm{hr}$ treatment with $100 \mathrm{nM}$ of exendin-4 (Ex-4), glucagon-like peptide-1 (GLP-1), or glucagon. cAMP levels in desiccated aliquots of cell extracts were measured by radioimmunoassay and used to calculate total cAMP content per well. Values are expressed as means \pm SE of reactions carried out in triplicate. $* * P<0.01, * * * P<0.001$ vs. control.

\section{Supplementary Figure 5}

Vildagliptin therapy does not change the relative levels of proglucagon, GIP or DPP4 mRNA transcripts in the intestine of WT and DIRKO mice. RNA was prepared from duodenum, jejunum an ileum ( $\mathrm{n}=6-7$ per group). Gene expression levels were 
determined by Real time PCR and normalized to levels of actin RNA as described in Methods. 